YEARBOOK of ANTITRUST and REGULATORY STUDIES www.yars.wz.uw.edu.pl
Peer-reviewed scientific periodical, focusing on legal and economic issues of antitrust and regulation. Creative Commons Attribution-No Derivative Works 3.0 Poland License.

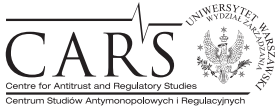

Centre for Antitrust and Regulatory Studies, University of Warsaw, Faculty of Management www.cars.wZ.uw.edu.pl

\title{
Piecemeal Harmonisation Through the Damages Directive? Remarks on What Received Too Little Attention in Relation to Private Enforcement of EU Competition Law
}

\author{
by
}

Anna Piszcz*

\section{CONTENTS}

I. Introduction

II. Range of remedies

1. Range of remedies under the body of sources predating the Directive

2. Claims for damages under the Directive - how broad is the meaning of this concept?

3. Other remedies

4. Attempt at assessment

III. A few other narrow concepts

IV. Summary

\section{Abstract}

On 11 June 2013, the European Commission adopted a package of measures to tackle the lack of an efficient and coherent private enforcement system of EU competition law in its Member States. In particular, a draft Damages Directive was proposed in order to meet the need for a sound European approach to private enforcement of EU competition law in damages actions. The Damages Directive was ultimately adopted on 26 November 2014. This paper explores some aspects of private antitrust enforcement which have not received sufficient attention from the EU decision-makers during the long preparatory and legislative works preceding the Directive. The paper discusses also some of the remedies that have not been harmonised, and shows how these 'gaps' in harmonisation may limit the

* Dr. Hab., Professor at the University of Białystok (Poland), Faculty of Law, Temporary on Duty of Chairman of the Department of Public Economic Law; member of the Advisory Board to the UOKiK President; e-mail: piszcz@uwb.edu.pl. 
Directive's expected influence on both the thinking and practice of private antitrust enforcement in Europe. It is argued in conclusion that further harmonisation may be needed in order to actually transform private enforcement of EU competition law before national courts.

\section{Résumé}

Le 11 Juin 2013, la Commission européenne a adopté un train de mesures pour lutter contre l'absence de système efficace et cohérent d'application privée du droit de la concurrence dans l'UE et dans ses Etats membres. En particulier, un projet de la Directive relative aux actions en dommages a été proposé afin de répondre au besoin d'introduction d'une approche européenne à l'application privée du droit européen de la concurrence. La Directive relative aux actions en dommages a été finalement adoptée le 26 Novembre 2014. Cet article analyse certains aspects de l'application privée du droit de la concurrence qui n'ont pas reçu l'attention suffisante de la part du législateur européen durant les longs travaux préparatoires et législatifs qui ont précèdes l'adoption de la Directive. Larticle aborde également certaines solutions qui n'ont pas été harmonisées et montre comment ces « lacunes » dans le processus d'harmonisation peuvent limiter l'influence de la Directive à la pratique et l'interprétation d'application privée du droit de la concurrence en Europe. En conclusion, l'article affirme que l'harmonisation plus profonde peut être nécessaire afin de transformer réellement l'application privée du droit européen de la concurrence devant les cours nationales.

Key words: private enforcement; competition; remedies; action for damages; claim for damages; unjust enrichment; undue performance; declaration of invalidity; injunctions.

JEL: K23; K42.

\section{Introduction}

National courts of EU Member States are required to safeguard rights created under Articles 101 and 102 of the Treaty on the functioning of the European Union (hereafter, TFEU). As the Court of Justice of the EU eloquently explained in Courage/Crehan and Manfredi ${ }^{1}$, detailed national procedural rules governing private actions for safeguarding such rights must not be less favourable than those governing similar domestic actions (principle

\footnotetext{
${ }^{1}$ See ECJ judgments in cases: C-453/99 Courage/Crehan (ECR 2001, I-06297); C-295-298/04 Manfredi et al. (ECR 2006, I-06619).
} 
of equivalence), and must not render the exercise of rights conferred by EU law practically impossible or excessively difficult (principle of effectiveness).

The European Commission (hereafter, Commission or EC) has been working for many years to make private enforcement viable for victims of EU competition law infringements. Some degree of harmonisation of the enforcement of rights granted under EU competition law has been considered necessary, especially because the major divergences in applicable national rules might threaten the proper functioning of the internal market. The Directive of the European Parliament and of the Council on certain rules governing actions for damages under national law for infringements of the competition law provisions of the Member States and of the European Union (hereafter, Directive or Damages Directive), proposed in 2013 by the Commission, was finally adopted on 26 November $2014^{2}$. The Directive seems to have the potential to transform the legal landscape with respect to actions for damages (damages actions) for infringements of competition law. Although commentators seem to take the scope of the Directive for granted, the act actually only covers rules concerning actions for damages. Indeed, only this type of claim is covered by the harmonisation. Is this appropriate?

This leads to the question whether it will be possible to make private antitrust enforcement emerge and develop in Member States, which have clearly lacked such enforcement so far. If the Directive is not complete enough to achieve this goal, how remote is the system from 'complete' harmonisation? The term 'piecemeal' used in the title of this paper means 'made out of bits and pieces'. Given that actions for damages are only one bit or one piece of private enforcement of competition law, and that the Directive refers solely to actions for damages (why is it like this?), is it possible that the above EU act is only the first bit or the first piece of a wider harmonisation process concerning private enforcement of EU competition law? Is there going to be a piecemeal harmonisation of private enforcement of EU competition law? The reason this question is asked here is that there are some aspects of private antitrust enforcement that have received too little attention from EU decision-makers in the many years of the preparatory and legislative works on the Directive $^{3}$.

2 Directive 2014/104/EU of the European Parliament and of the Council of 26 November 2014 on certain rules governing actions for damages under national law for infringements of the competition law provisions of the Member States and of the European Union, OJ L 349, 05.12.2014, p. 1 .

${ }^{3}$ See also K. Havu, 'Quasi-Coherence by Harmonisation of EU Competition Law-Related Damages Actions?' [in:] P. Letto-Vanamo, J. Smits (eds.), Coherence and Fragmentation in European Private Law, Sellier European Law Publishers, Munich 2012, p. 41. Two years before the adoption of the Directive, the author was afraid that the project was likely to leave a significant portion of relevant law out of the scope of the harmonisation. In her view, it was questionable what kind of effects such harmonisation would have. 
The scope of the Directive seems too limited overall. Furthermore, some of its definitions are characterized by a considerable degree of narrowness. A number of examples of such definitions will be considered in this paper, which were drafted in the Directive in a way which makes national interpretation (and drawing inspiration from national legal tradition) pretty difficult.

\section{Range of remedies}

\section{Range of remedies under the body of sources predating the Directive}

It is widely assumed that the discussion on private enforcement of EU competition law has been provoked by the Court of Justice (hereafter, CJ or Court) which ruled on, inter alia, the seminal Courage/Crehan and Manfredi cases $^{4}$. Actions (claims) for damages for harm caused by infringements of EU competition rules have dominated the attention of the CJ in the above cases. In Manfredi, the Court held, however, that 'any individual can rely on the invalidity of an agreement or practice prohibited under that article [current Article $101 \mathrm{TFEU}$ ] and, where there is a causal relationship between the latter and the harm suffered, claim compensation for that harm'. In considering this, the $\mathrm{CJ}$ has tended to expand the scope of the articulated remedies to include not only actions for damages, but also declaratory relief. Indeed, victims of EU antitrust violations rely on invalidity in practice - their claims are not only for damages but also, for example, for the declaration of invalidity.

In turn, the main sources of relevant information on the Commission's approach to private enforcement of EU competition rules can be identified as: (1) the Green Paper of 2005 - Damages actions for breach of the EC antitrust

${ }^{4}$ See eg I.S. Forrester, 'Searching Beneath the Cherry Tree in the Garden: European Thoughts on How to Enhance the Task of Uncovering and Thereby Deterring Cartels' [in:] C.-D. Ehlermann, I. Atanasiu (eds.), European Competition Law Annual 2006: Enforcement of Prohibition of Cartels, Hart Publishing, Oxford-Portland 2007, p. 179-181; A. Johnston, "Spillovers" from EU Law into National Law: (Un)intended Consequences for Private Law Relationships' [in:] D. Leczykiewicz, S. Weatherill (eds.), The Involvement of EU Law in Private Law Relationships, Hart Publishing, Oxford-Portland 2013, p. 363 et seq., A. JurkowskaGomułka, Publiczne i prywatne egzekwowanie zakazów praktyk ograniczających konkurencję: $w$ poszukiwaniu zrównoważonego modelu wspótistnienia, Wydawnictwo Naukowe Wydziału Zarządzania Uniwersytetu Warszawskiego, Warszawa 2013, p. 122; A. Piszcz, 'Dyrektywa odszkodowawcza 2014/104/UE - przegląd niektórych rozwiązań' (2015) 4(4) internetowy Kwartalnik Antymonopolowy i Regulacyjny 76. See also G. Niels, R. Noble, 'Quantifying Antitrust Damages - Economics and the Law' [in:] K. Hüschelrath, H. Schweitzer (eds.), Public and Private Enforcement of Competition Law in Europe: Legal and Economic Perspectives, Springer, Berlin-Heidelberg 2014, p. 122-123, regarding policy principles behind damages claims. 
rules (hereafter, the Green Paper) ${ }^{5}$ and (2) the White Paper of 2008 on damages actions for breach of the EC antitrust rules (hereafter, the White Paper) ${ }^{6}$. It is clear already from their titles that the Papers were both devoted to damages actions alone. However, the Green Paper explained that: 'damages claims are part of the enforcement system of Community antitrust law. Private enforcement [...] means application of antitrust law in civil disputes before national courts. Such application can take different forms. Article 81(2) of the Treaty states that agreements or decisions prohibited by Article 81 [current Article 101 TFEU] are void. The Treaty rules can also be used in actions for injunctive relief. Also, damages awards can be awarded to those who have suffered a loss caused by an infringement of the antitrust rules. This Green Paper focuses on damages actions alone'.

This seems to confirm the view that the Commission knew perfectly well already over a decade ago that private antitrust enforcement might occur also in ways other than by way of damages actions (albeit the above remedies are still not the 'whole story' of private antitrust enforcement). The first other remedy that can be deduced from the Green Paper is declaratory relief (the declaration of invalidity of an agreement, decision of association of undertakings or practice), the second is injunctive relief (where the plaintiff requests the court to order the infringer to stop the violation and/or remove its effects).

Predictably, the White Paper focused on damages actions alone. In fact, it did not even contain an explanation similar to the one provided in the Green Paper. This shift might have been a reflection of a simultaneous change in the approach of the Commission towards the determination of the (ultimate) aims of the harmonisation. What followed was an extensive debate on this topic which seemed to view the choice in that matter as one between the contribution of private enforcement to the EU competition law enforcement system (plus its full effect), and the victims' right to compensation ${ }^{7}$. While the Green Paper focused on the 'system-oriented' goal, in the White Paper, private enforcement was conceived more in terms of compensation to be available to victims who suffered harm as a result of EU antitrust infringements.

\section{Claims for damages under the Directive - how broad is the meaning of this concept?}

In the Directive, it is evident that the scope of the harmonised remedies for breaching EU competition rules is confined merely to actions (claims) for damages. According to its very title, the scope of the Directive is limited

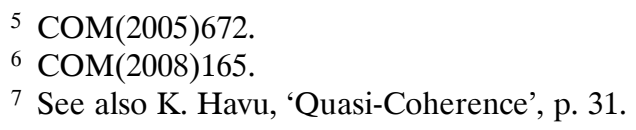


to certain rules governing actions for damages under national law for infringements of the competition law provisions of the Member States and of the European Union.

An action for damages is merely one possible tool among a far more varied set of remedies that might be used for breaches of EU competition rules. The Directive alone confirms that '[a]ctions for damages are only one element of an effective system of private enforcement of infringements of competition law' (Recital 5 of the Preamble). If they are only a partial cutaway of a diverse system, how are they complemented by other elements? The Directive states that they are complemented by 'alternative avenues of redress'. It is clear therefore that the Parliament and the Council believe that a system of private enforcement comprises redress or, more precisely, avenues of redress - both 'traditional' (damages actions brought before courts) and 'alternative' ones.

The first issue here is the meaning of the word 'redress'. According to its ordinary meaning as used by the $\mathrm{EC}^{8}$, redress is apt to encompass: (1) compensatory redress and (2) injunctive redress. The latter covers legal mechanisms that ensure a possibility to claim (respectively): (1) compensation of harm, (2) cessation of the illegal behaviour and/or removal of its effects. Yet it is justifiable to say that a broader meaning, which includes not only monetary relief and injunctive relief but also declaratory relief (the declaration of invalidity), more accurately reflects the current system of private enforcement in Europe. The second issue concerns 'alternative avenues' of redress. Two of them are determined in Recital 5 of the Preamble to the Directive. The latter addresses, first, consensual dispute resolution, which receives a great deal of emphasis in the Directive in general. It is a striking fact, however, that the same Recital also suggests that - in an effective system of private antitrust enforcement - actions for damages are complemented by alternative avenues of redress in the form of 'public enforcement decisions that give parties an incentive to provide compensation'. Its seems fair to claim that ideally private and public enforcement should be designed so that they complement each other ${ }^{9}$ and that infringers should be first persuaded to compensate their victims

8 See eg Commission Recommendation of 11 June 2013 on common principles for injunctive and compensatory collective redress mechanisms in the Member States concerning violations of rights granted under Union Law, OJ L 201, 26.07.2013, p. 60.

9 See eg F.G. Jacobs, T. Deisenhofer, 'Procedural Aspects of the Effective Private Antitrust Enforcement of EC Competition Rules: A Community Perspective' [in:] C.-D. Ehlermann, I. Atanasiu (eds.), European Competition Law Annual 2001: Effective Private Enforcement of EC Antitrust Law, Hart Publishing, Oxford-Portland 2003, p. 198; A.P. Komninos, 'The Relationship between Public and Private Enforcement: quod Dei Deo, quod Caesaris Caesari' [in:] P. Lowe, M. Marquis (eds.), European Competition Law Annual 2011: Integrating Public and Private Enforcement of Competition Law - Implications for Courts and Agencies, Hart Publishing, 
voluntarily ${ }^{10}$. The view cannot be accepted, however, that public enforcement decisions, which incentivise parties, are an element of private enforcement. Public enforcement decisions are still an element of public enforcement, no matter how much both parts of the antitrust enforcement system interact with each other. To sum up, Recital 5 seems to add little to the understanding of the concept of a 'private antitrust enforcement system'.

Switching back to damages actions, it should be said first of all that an 'action for damages' is, in short, an action under national law by which a claim for damages is brought before a national court (Article 2(4) of the Directive). Furthermore, a 'claim for damages' is a claim for compensation for harm caused by a competition law infringement (Article 2(5)). How should this notion be understood? What are 'compensation' and 'harm'? It is essential to remember that the delimitation of these two concepts will have major implications for how the scope of actions (claims) to be harmonised is conceived by national legislators. Actions (claims) classified by them as damages actions (claims) shall benefit from the provisions of the Directive. They will thus place claimants, at first glance, in a privileged position. They range from provisions on disclosure of evidence, on the effect of decisions issued by National Competition Authorities (hereafter, NCAs,), limitation periods, joint and several liability, the passing-on of overcharges, quantification of harm, to provisions on consensual dispute resolution.

As rightly observed by $\mathrm{K}$. Havu ${ }^{11}$, some elements of the Directive shall require national interpretation and drawing inspiration from national legal tradition. The notion of an action (claim) for damages and underlying concepts seems to be one of these concepts. Central to these issues is the notion of harm. In Poland, civil theorists construe harm in a restrictive manner. It is essentially a difference between the position of the injured party caused by the harming event, and the position he would have been in had there been no harming event ${ }^{12}$. Compensating for harm represents a specific category of phenomena within a broader category of remedies. Under Polish law, restitution based on unjust (baseless) enrichment is a category of remedies different from compensation for harm ${ }^{13}$. It is not aimed at compensating the claimant, but at reversing the enrichment. It forces the other party to disgorge

Oxford-Portland 2014, p. 141 et seq. See also A. Jurkowska, 'Antitrust Private Enforcement Case of Poland' (2008) 1(1) YARS 75.

10 A. Piszcz, 'Still-unpopular Sanctions: Developments in Private Antitrust Enforcement in Poland After the 2008 White Paper' (2012) 5(7) YARS 76.

11 K. Havu, 'Quasi-Coherence', p. 32.

12 See M. Kaliński, Szkoda na mieniu i jej naprawienie, CH Beck, Warszawa 2011, p. 168 and literature cited therein; W. Czachórski, A. Brzozowski, M. Safjan, E. Skowrońska-Bocian, Zobowiazania. Zarys wyktadu, Wydawnictwa Prawnicze PWN, Warszawa 1999, p. 95 et seq

13 See also M. Kaliński, Szkoda, p. 206-208. 
benefits (which would be unjust for him to keep) in kind or, should this be impossible, refund their value in cash. It is argued that in practice, claims for restitution based on unjust enrichment generally entail evidentiary difficulties comparable to the assertion of damages claims ${ }^{14}$.

Undue performance is a special type of unjust enrichment ${ }^{15}$. In this case, a benefit is obtained in the form of a received performance. The unjustness of the enrichment results from, inter alia, the fact that the legal action which obliged a party to make the performance was void and did not become valid after the performance was made (Article 410 of the Civil Code ${ }^{16}$ of 23 April 1964). Restitution based on undue performance is a remedy available in Poland in the case of antitrust infringements. It results from the fact that both anticompetitive agreements and agreements (legal actions) concluded as a result of the abuse of dominance are void - irrespective of whether they simultaneously infringe Article 101 or 102 TFEU or not (Article 6 para 2 and Article 9 para 3 of 16 February 2007 on competition and consumers protection ${ }^{17}$ ). In some competition cases, claims submitted by injured parties shall thus be classified as claims for restitution resulting from the invalidity of the agreement, rather than claims for damages (compensation of harm).

While the above discussion focused on the Polish example, the same issue seems to exist in other Member States also. To name but a few, the Czech Republic and Germany are mentioned in literature to have this type of claim in competition cases $^{18}$. Moreover, German law allows for the skimming-off of profits made as a result of illegal market conduct (ill-gotten gains), provided that the defendant's conduct has been intentional and the defendant has gained economic benefits at the expense of a wide range of market participants ${ }^{19}$. In the case of small and dispersed claims, no single market participant (like a consumer) has an incentive to sue the infringer. Associations representing the interests of an industry, trade or service sector

14 See P. Podrecki, 'Civil Law Actions in the Context of Competition Restricting Practices under Polish Law' 2009 2(2) YARS 92.

15 See A. Brzozowski, 'Civil Law (Law of Contracts, Property and Obligations)' [in:] S. Frankowski (ed.), Introduction to Polish Law, Kluwer Law International, the Hague 2005, p. 74.

16 Consolidated text Journal of Laws of 2014, item 121, as amended.

17 Consolidated text Journal of Laws of 2015, item 184.

18 L. Bányaiová, 'Czech Republic' [in:] S. Mobley (ed.), Private Antitrust Litigation in 27 jurisdictions worldwide, Law Business Research Ltd, London 2010, p. 35; P.L. Landolt, Modernised EC Competition Law in International Arbitration, Kluwer Law International, the Hague 2006, p. 352.

19 See A. Stadler, 'Collective Action as an Efficient Means for the Enforcement of European Competition Law' [in:] J. Basedow (ed.), Private Enforcement of EC Competition Law, Kluwer Law International, Aalphen aan den Rijn 2007, p. 206 et seq. 
(but not consumer associations), and meeting the criteria set by competition law, are therefore entitled to request from the court that the defendant's illegally-gained profits be remitted to the federal treasury (rather than to the association or its members). Actions by associations are subsidiary to decisions of the competition authority, depriving the violator of the benefits of illegal conduct. This seems to be a means to aggregate claims arising from the same facts and to make sure that they do not remain unpaid. Even if they cannot satisfy the injured parties, it is better if ill-gotten gains are transferred to the federal treasury, than left with the infringer. This 'half-a-loaf-is-better-than-noloaf' philosophy might have increased the number of private antitrust lawsuits and might have deterring effects on possible antitrust violations. However, the skimming-off mechanism seems at first glance to deter potential plaintiffs. Associations which are granted standing do not appear to be in a position to have a financial interest in a successful lawsuit. This may explain why, as of 2013, no such case has ever been brought before German courts ${ }^{20}$.

Are the abovementioned causes of court actions distinct from the causes of damages actions within the meaning of the Directive? To this question, the answer is in affirmative. Even if they take the form of actions for monetary claims (other than damages), their function is not to compensate for harm suffered by the injured party. Article 3 para 2 of the Directive, which stipulates the principle of full compensation, provides that the meaning of the term 'harm' is similarly narrow to the Polish context. It is said therein that full compensation shall place a person who has suffered harm in the position in which that person would have been had the infringement of competition law not been committed; it shall therefore cover the right to compensation for actual loss (damnum emergens) and for loss of profit (lucrum cessans), plus the payment of interest. It is also worth mentioning that EU law draws a distinction between claims for damages and claims for restitution. This is shown in the wording of Article 5 para 4 of Council Regulation 44/2001 of 22 December 2000 on jurisdiction and the recognition and enforcement of judgments in civil and commercial matters ${ }^{21}$ which refers to 'a civil claim for damages or restitution'.

However, would this line of reasoning be followed by the Court of Justice if it were to decide on the scope of the notion of damages under the Damages Directive? The possibility should not be ruled out that the Court could go beyond the direct meaning of the text of the Directive and the need for coherence in the wording of the EU legislation. However, such broad interpretation cannot be considered to have a sound basis. Undoubtedly, private antitrust

${ }^{20}$ S.V. Walle, Private Antitrust Litigation in the European Union and Japan: A Comparative Perspective, Maklu, Antwerpen-Apeldoorn 2013, p. 180.

21 OJ L 12, 16.01.2001. 
enforcement in EU Member States consists of a heterogeneous, complex and perhaps even chaotic group of remedies with varied procedural characteristics. This does not seem in line with the trend towards an effective system of private antitrust enforcement. Yet the scope of the Directive - too narrow to make the system into an efficient and cohesive 'whole' - must not become broadened by jurisprudence and an expansive functional interpretation employed thereby. This is so especially because EU Member State must rely on the specific definitions contained in the Directive for the purpose of its transposition.

\section{Other remedies}

Mentioned besides claims for damages must also be claims for restitution based on unjust enrichment and the abovementioned claims for the skimmingoff of profits. The second part of a private antitrust enforcement system consists of civil disputes where: (1) declaratory relief is claimed (the declaration of invalidity, that is, the declaration that an agreement, decision of association of undertakings or practice is void); (2) injunctions are claimed (a court order to bring the infringement to an end and/or remove its effects ${ }^{22}$ ).

As to declaratory relief, it should be noted that practices prohibited by Article 101(1) TFEU are void, no prior decision to this effect being necessary. Interestingly however, the scope of the TFEU's rule of invalidity does not cover agreements concluded as a result of an abuse of dominance. By doing so, the EU legislator let EU Member States decide freely on whether agreements (legal actions) infringing EU competition rules in the area of abuse are legally void or not.

Polish competition law stipulates the 'automatic' sanction of invalidity for agreements (legal action) infringing both of the antitrust prohibitions anticompetitive agreements and the abuses of dominance. In Poland, invalidity is used primarily as a defensive strategy ('shield') ${ }^{23}$ in response to claims for performance or claims for damages because of non-performance. Burden of proof lies here on the party asserting the invalidity of the agreement (pleading the invalidity of a contractual provision it has itself signed). A contractual party can also seek a determination of the agreement's (or affected clauses') invalidity, upon a petition for a declaratory judgment, if there are no other possibilities to protect its rights. Nevertheless, above all, the invalidity must be invoked by a court ex officio.

22 See also P. Podrecki, 'Civil Law Actions', p. 83.

23 A. Jurkowska, 'Antitrust', p. 74. 
The Damages Directive does not refer to actions using invalidity, irrespective of whether they use it defensively or offensively - except for actions for antitrust damages where invalidity is invoked for particular purposes.

Importantly in relation to injunctions, victims of EU competition law violations may, instead of using private enforcement, file a complaint to a competition authority or - where the initiation of proceedings on a complaint basis is not available (for instance in Poland) - inform the competition authority of the violation. It is possible that in the wake of such complaint or information an infringement decision will be rendered by the competition authority. Public enforcement, compared to private actions for injunctions, may be extremely effective both in terms of the length of proceedings and costs on the part of victims (Polish public enforcement is an example thereof). The latter, turning towards public enforcement, may avoid costly and long-lasting litigation. Nevertheless, it is argued that applications for injunctive relief hold in many EU jurisdictions a prominent place in their private enforcement system; they are common, certainly more common than actions for damages ${ }^{24}$. This may be caused, inter alia, by the fact that competition authorities (EC, NCAs) usually do not have the resources to investigate every problem brought to their attention, thus they have to set priorities (case prioritisation) and focus on most serious infringements only. Where competition authorities refuse to initiate public proceedings, and a party decides to a court for an injunction, harmonised pro-plaintiff provisions on the effect of NCAs' decisions would be useless. However, the Directive does contain many other pro-plaintiff provisions that would help fulfil the claimant's burdens. However, claims for injunctions are not referred to by the Directive at all, as their main function is not to compensate for harm incurred but to allow those being harmed (or threatened with harm) by an antitrust violation to prevent (further) harm from occurring. Therefore, they do not fall within the scope of the notion of actions for damages as defined in the Directive.

\section{Attempt at assessment}

The question arises why did the EU legislator leave private enforcement actions other than actions for damages outside the scope of the Directive. Was it a matter of faith in the effectiveness of damages actions alone? It seems that decision-makers knew that their goal should have been more than just to try to ensure effective actions for damages. Yet they faced a fundamental dilemma surrounding the problem of 'quickness versus completeness'.

24 S.V. Walle, Private Antitrust Litigation, p. 203, 224. 
Emphasis on actions for damages is deeply rooted in EU jurisprudence and the EC's Green and White Papers. By contrast, assessments providing greater insights into other private enforcement remedies were not easily available. More importantly, a political agreement was reached on the harmonisation of national rules to enable private enforcement of EU competition rules via damages actions - the consensus did not cover other types of actions. When drafting the proposal for the Directive and accompanying documents ('harmonisation package'), the EC opted so to speak for a 'bird in the hand', rather than 'two in the bush'.

The attempt to harmonize private enforcement of EU competition law through the Damages Directive may in fact result in evolutionary rather than revolutionary effects. The outcome is fragmented, as it focuses on how to reduce differences in national rules governing actions for damages, and omits other remedies for EU antitrust breaches. The Directive can cause a real change in private enforcement of competition law, but subject to strict limits on remedies.

Recital 6 of the Preamble to the Directive declares that effective private enforcement actions under civil law and effective public enforcement by competition authorities must interact to ensure the maximum effectiveness of competition rules. It is therefore necessary to 'regulate the coordination of those two forms of enforcement in a coherent manner'. Yet it is said in Article 1 para 2 that the Directive sets out rules coordinating the enforcement of competition law by competition authorities and their enforcement in damages actions ${ }^{25}$ before national courts. This harmonisation scope may have consequences for the effectiveness of the private EU antitrust enforcement system, endorsed so frequently in the text of the Directive. Some Member States have a system of procedural and substantive rules that shows a predominance of other private enforcement actions over claims for damages. In those jurisdictions, an increase in the effectiveness of private enforcement can probably not be achieved thanks to the Directive and its focus on damages actions. This aim may be undermined even after the rules for the transposing of the Directive are fine-tuned and come into force.

It is worth adding that it seems slightly misleading to speak of 'the competition law provisions of the Member States' in the title of the Directive. In the definition contained in Article 2(3), national competition law is limited to provisions of national law that are applied to the same case and in parallel to EU competition law pursuant to Article 3(1) of Council Regulation 1/2003 of 16 December 2002 on the implementation of the rules on competition laid down in Articles 81 and 82 of the Treaty ${ }^{26}$. The Directive should not affect

25 Emphasis added by the author.

26 OJ L 1, 04.01.2003, p. 1. 
actions for damages with respect to infringements of national competition law which do not affect trade between Member States within the meaning of Article 101 or 102 TFEU (last sentence of Recital 10 of the Preamble). It is thus justified to say that for these matters the Directive does not require Member States to model their legal frameworks on the Directive; albeit they are free to do so. However, it does not seem reasonable for Member States to have double standards with respect to the two different types of infringements (those with and those without EU effect), as this would make private antitrust enforcement even more difficult for courts and parties. Most probably, national rules governing actions for damages will be modelled on the Directive not only with regard to infringements of EU competition rules (and national rules applied in parallel) but also with regard to violations of national competition law which do not affect EU trade (infringements of a purely national scope). Private claimants enforcing EU competition rules through actions other than actions for damages may find themselves in the 'missing middle' between those two beneficial frameworks.

Particularly for private antitrust actions for monetary claims other than damages, it is difficult to understand why claimants should not be able to benefit from 'privileges' enjoyed by those claiming damages. These could include rules on the effect of NCAs' decisions, rules on disclosure of evidence, or rules on limitation periods (and in particular their suspension or interruption). An antitrust infringement found by a final decision of a competition authority shall be deemed to be irrefutably established in the case of damages actions. Why then should a 'non-damages' claimant be required to prove an infringement, instead of relying upon a final decision, in case of other private enforcement actions?

On the other hand, there is no clarity as to the application of the law in a situation where various claims are combined in the same proceedings, such as a claim for restitution based on undue performance and a claim for damages (this is permissible under Polish laws). At first glance, it seems that national courts should apply two different sets of rules in such cases - this may prove quite ineffective. Admittedly, this will not be very difficult in the case of rules on, for instance, limitation periods. However, many more complications may arise because of the application of two different sets of rules on evidence disclosure of or the effect of NCAs' decisions. This will result in a double standard in relation to evidence. How should this issue be reasonably approached? Will it be possible to adduce evidence disclosed for the purpose of claiming damages in support of the other claim? Will it be possible to claim damages (even 'symbolic') just so it is easier to prove other claims and withdraw the former at a later stage of the proceedings? The narrowness of the concepts of an 'action' and a 'claim' employed by the Directive may result 
in considerable difficulties not only for national legislators, but also courts and procedural parties. Something should be done to solve them.

Therefore, it is postulated here to harmonize rules on a wide range of private antitrust remedies - it is better to turn to a 'piecemeal', progressive harmonisation than to confine ourselves to the Damages Directive only. It is not alleged here that Member States voluntarily model their legal frameworks for claims other than damages on the framework adopted for the latter. Therefore, looking further ahead, it is suggested here that not later than after the first review of the Directive 'Private Antitrust Enforcement I', works on a proposal for a 'Private Antitrust Enforcement II' Directive should be commenced. There may be important lessons to be learned (from the practical application of national rules on damages actions introduced as a result of the Damages Directive) about how to shape rules on other private enforcement actions. Yet nothing suggests at the moment that further legislative works aimed at completing the system are envisaged for the future.

\section{A few other narrow concepts}

As shown above, certain problems with the interpretation of the Damages Directive and, consequently, its transposition by Member States, may lie in the narrowness of the scope of the concepts used in the Directive. A few further points are added below about the restrictiveness of some of the other notions covered by the Directive.

Among concepts worth addressing are the notion of a 'leniency statement' (related to the concept of a 'leniency programme'27) and a 'settlement submission'. These are concepts of public antitrust enforcement defined for the purpose of private enforcement in the form of damages actions - in Article 2(16) and 2(18) of the Directive. Provisions of the Directive on the protection of these types of 'presentations' satisfies the Commission's concerns about the impact of the harmonised rules on its leniency policy (which allows infringers to confess their part in breaches of competition laws in exchange for leniency in the imposition of fines $)^{28}$. The aim of these provisions is to protect certain public interests in relation to the cooperation of parties with the competition authority. Article 6 para 6 of the Directive provides therefore for the absolute protection from disclosure of leniency statements

27 Defined in Article 2(15) of the Directive.

${ }^{28}$ See eg C.H. Bovis, C.M. Clarke, 'Private Enforcement of EU Competition Law' (2015) 36 Liverpool Law Review 65-66. 
and settlement submissions ${ }^{29}$. However, neither definition translates well into the Polish national context for example. Both definitions were designed in a way strictly modelled on the respective concepts employed in EC soft law for the purpose of its own enforcement system. The scope of these concepts under national laws seems to have been simply ignored.

A 'settlement submission', within the meaning of the Directive, is not part of the Polish 'settlement' procedure - so called 'procedure for a voluntary submission to a fine' - which may be used in the case of any anticompetitive practices (unilateral or collective), hence not necessarily cartels. Therefore, the Directive does not provide a basis for Poland to maintain rules which - in cases regarding infringements of EU competition rules - would lead to the absolute protection of any 'settlement' documents at all, be it self-incriminating or not ${ }^{30}$. It shall be for national courts to decide, on a case-by-case basis, as to whether such documents shall be protected from disclosure or not. When assessing the proportionality of an order to disclose information, national courts shall consider, inter alia, the need to safeguard the effectiveness of public enforcement of competition law ${ }^{31}$.

Second, the Polish leniency programme differs from its EU equivalent to a considerable extent as it refers not only to cartels, but also to other agreements, decisions of associations of undertakings and concerted practices (horizontal or vertical). The transposition of the Directive shall result in the creation of two categories of leniency statements in cases with an EU element - those absolutely protected from disclosure (in the case of cartels in the meaning of the Directive ${ }^{32}$ ) and those subject to protection or disclosure based upon the decision of the court issued on a case-by-case basis (in other cases). The scope of national provisions implementing the Directive's rule on the absolute protection of leniency statements cannot be extended beyond cartels. Article 5 para 8 of the Directive only allows Member States to maintain or introduce rules which would lead to wider disclosure of evidence (subject to exceptions providing for absolute protection), and never to a narrower scope of disclosure.

${ }^{29}$ Such an absolute protection has, however, been criticised on the basis of the EU jurisprudence (preceding the Directive) and the CJ's interpretation of principles of primary law; see Ch. Kersting, 'Removing the Tension Between Public and Private Enforcement: Disclosure and Privileges for Successful Leniency Applicants' (2014) 5(1) Journal of European Competition Law \& Practice 3-4.

${ }^{30}$ In practice, self-incriminating information may be delivered by the party although provisions on the procedure of a voluntary submission to a fine does not actualy require it.

31 See Article 6(4)(c) of the Directive.

32 Article 2(14) of the Directive. Significantly, this is the first definition of a 'cartel' drafted in a hard law instrument (an this instrument consists of civil law provisions rather than competition law provisions). Through its implementation, this definition is going to spread across EU Member States (but only for the purpose of private enforcement of EU competition rules). 
This is undisputable. However, this also provokes a question regarding another aspect of leniency referred to in the Directive - its provisions set out benefits to immunity recipients with regard to their joint and several liability.

Focusing on cartels is a matter of policy choice. The scope of the EU leniency programme is limited to cartels (similarly with the EU settlement procedure $)^{33}$. Consequently, the definitions of a leniency programme and leniency statement, contained in Article 2(15) and 2(16) of the Directive, are limited to cartel-related issues only. In some Member States ${ }^{34}$, the respective definitions are designed and used - for the purposes of public enforcement more broadly to also cover agreements (and decisions of associations) other than cartels. In such cases, the transposition of the Directive shall result in a situation where a leniency applicant reporting a vertical agreement infringing Article 101 TFEU to the NCA will receive immunity from fines (or reduction thereof) but - in the event of private action for damages - will benefit neither from the absolute protection of his leniency statement nor the limitation of joint and several liability. These cartel-related privileges are intended to prevent cartel participants from: (1) being deterred from cooperating with competition authorities (Recital 26 of the Preamble) and (2) undue exposure to damages claims (Recital 38 of the Preamble). The question this provokes is whether participants to other anticompetitive agreements deserve, or not, incentives and rewards just as much as cartel participants do (especially since non-cartel practices are much less dangerous to market competition). If not, does a 'wider-than-cartels' scope of a national leniency programme constitute a wrong policy choice? Should national leniency programmes be redesigned? An afterthought arises at this point. Maybe the circumstances have been too premature for the harmonisation of civil procedures, since Europe is still characterised by a great complexity of national solutions and considerable divergences in, for instance, leniency programmes or settlement procedures.

On the other hand, the Directive provides certain special 'benefits' not only for cartel participants but also for their victims. As a rule, provisions of the Directive apply equally to infringements of Article 101 and infringements of Article 102 TFEU. There is, however, one presumption - benefitting injured parties - which would only apply in the case of cartels. This is the rebuttable

33 The definition of a leniency programme contained in Article 2(15) refers to a 'secret cartel'. This additional adjective seems superfluous, especially since sometimes cartels are not as secret as it might seem at first glance; see an example analysed in: J. Faruga, 'Case comment on the decision issued by the European Commission in the case AT.39792 - Steel Abrasives' (2014) 8(2) Studia Prawnicze i Administracyjne 5.

34 As to Sweden see K. Karlsson, P. Hansson, 'Sweden' [in:] J. Buhart, Leniency Regimes: Jurisdictional Comparisons, Sweet \& Maxwell, London 2012, p. 302. 
presumption implying that cartel infringements cause harm (Article 17 para 2 of the Directive). The existence of presumptions is believed to serve as an incentive to litigation or, reversing the argument, the lack of presumptions can act as a barrier to private enforcement ${ }^{35}$. Unlike cartels, other infringements of EU competition rules shall not result in such presumption.

The key reason for this is presented in Recital 47 (fourth sentence) of the Preamble which states that 'It is appropriate to limit this rebuttable presumption to cartels, given their secret nature, which increases the information asymmetry and makes it more difficult for claimants to obtain the evidence necessary to prove the harm'. This justification does not seem convincing - the presumption seems too narrow and should cover more than just cartels. Secrecy is not exclusive to cartels, and neither is lack of information, which makes it difficult for claimants to obtain the evidence necessary to prove their harm. Similar problems can be identified in particular in the case of pricing practices other than cartels such as, for example, exploitative abuses of dominance. On the other hand, there are other reasons for a narrow scope of such presumption. It is argued, that the risk that non-cartel infringements are actually not harmful for consumers ('false positives') is much higher than in cartel cases, where harm to consumers is almost certain ${ }^{36}$. Therefore, the presumption only seems too narrow 'on the surface' - it is indeed appropriate that only cartel victims shall benefit from it.

By way of digression, a question should be asked whether the presumption is actually going to prove of real benefit for victims of antitrust violations. Subject to Article 17(1) of the Directive, injured parties will still have to prove the amount of the harm suffered. Although victims received the above presumption 'in exchange for' the introduction of absolute protection of settlement submissions and leniency statement (which affects them adversely), this 'barter' appears unfavourable to the injured parties. The problem lies also in the current trend that sees a truly extensive use of settlement decisions and leniency applications, at least in proceedings before the Commission. This may result in practice in even more difficulties with access to evidence included in the competition authorities' cartel files. As a result, the procedural position of a cartel victim - even with the presumption of harm - is not going to be much better than the position of other injured entities.

35 See also O. Odudu, 'Developing private enforcement in the EU: Lessons from the Roberts Court' (2008) 53(4) The Antitrust Bulletin 875 et seq.

36 J. Alfaro, T. Reher, 'Towards the Directive on Private Enforcement of EC Competition Law: Is the Time Ripe?' (2010) The European Antitrust Review 44. 


\section{Summary}

The Directive is selective - hence the harmonisation of private enforcement of EU competition law is selective. While in charge of the preparatory works on the harmonisation package, the EC has admittedly recognised that private antitrust enforcement might occur also in ways other than by way of actions for damages (see Part II.1 of this article). This paper considers a number of possible reasons (Part II.4) why the scope of the harmonisation was ultimately limited to actions (claims) for damages only. However, as it has been exemplified in Part II.2 and II.3, other private enforcement remedies are available alongside damages actions in proceedings before national courts. To name but a few, victims of EU competition law violations might pursue restitution or injunctions claims as well as claims for the declaration of invalidity. Undoubtedly, claims for injunctive relief and claims for declaratory relief do not fall within the scope of the Directive (Part II.3 of the article). On the other hand, the monetary nature of some restitution claims (or skimming-off of profits known in German law) has prompted a reflection upon the question whether they fall within the category of claims for damages according to the definition contained in the Damages Directive (Part II.2 of the article). An affirmative response would seem to defy the logic of the legal source that the definition operates in. Based on arguments that have been developed above, a negative response has thus been given.

The paper has shown that the Directive's narrow scope is an important characteristic of the recent harmonisation effort concerning private enforcement of EU competition law. However, the advantage of the narrow approach of EU decision-makers to the harmonisation scope lies in that it made the harmonisation possible at an earlier stage, albeit it is incomplete (piecemeal?). As a result, a comment de lege ferenda has been presented here (Part II.4) suggesting that the Damages Directive should not become the end of the harmonisation story for private antitrust enforcement in Europe and that further works thereon should be seen as more than merely an abstract idea.

The narrowness of the concepts employed by the Directive can also be seen in some of the definitions referred to in this paper (Part III) - the EU legislator modelled them on concepts that exist in EC soft law for the purpose of the Commission's own public enforcement. Possible difficulties for EU Member States have been identified when it comes to adapting their laws because of the divergence that persists across Europe. As a result, some definitions contained in the Directive do not translate well into specific national contexts. In order to implement the Directive, EU Member States will indisputably need to conduct an intensive scrutiny of varied domestic legal fields including competition law, civil law and procedural law. 
To sum up, the narrowness of the scope of the harmonisation through the Damages Directive and the problems that are likely to arise when working on its transposition may partly waste the capacity for improvements in private antitrust enforcement in Europe.

\section{Literature}

Alfaro J., Reher T., 'Towards the Directive on Private Enforcement of EC Competition Law: Is the Time Ripe?' (2010) The European Antitrust Review

Bányaiová L., 'Czech Republic' [in:] S. Mobley (ed.), Private Antitrust Litigation in 27 jurisdictions worldwide, Law Business Research Ltd, London 2010.

Bovis C.H., Clarke C.M., 'Private Enforcement of EU Competition Law' (2015) 36 Liverpool Law Review

Brzozowski A., 'Civil Law (Law of Contracts, Property and Obligations)' [in:] S. Frankowski (ed.), Introduction to Polish Law, Kluwer Law International, the Hague 2005.

Czachórski W., Brzozowski A., Safjan M., Skowrońska-Bocian E., Zobowiazania. Zarys wyktadu, Wydawnictwa Prawnicze PWN, Warszawa 1999.

Faruga J., 'Case comment on the decision issued by the European Commission in the case AT.39792 - Steel Abrasives' (2014) 8(2) Studia Prawnicze i Administracyjne.

Forrester I.S., 'Searching Beneath the Cherry Tree in the Garden: European Thoughts on How to Enhance the Task of Uncovering and Thereby Deterring Cartels' [in:] C.-D. Ehlermann, I. Atanasiu (eds.), European Competition Law Annual 2006: Enforcement of Prohibition of Cartels, Hart Publishing, Oxford-Portland 2007.

Havu K., 'Quasi-Coherence by Harmonisation of EU Competition Law-Related Damages Actions?' [in:] P. Letto-Vanamo, J. Smits (eds.), Coherence and Fragmentation in European Private Law, Sellier European Law Publishers, Munich 2012.

Jacobs F.G., Deisenhofer T., 'Procedural Aspects of the Effective Private Antitrust Enforcement of EC Competition Rules: A Community Perspective' [in:] C.-D. Ehlermann, I. Atanasiu (eds.), European Competition Law Annual 2001: Effective Private Enforcement of EC Antitrust Law, Hart Publishing, Oxford-Portland 2003.

Johnston A., "'Spillovers" from EU Law into National Law: (Un)intended Consequences for Private Law Relationships' [in:] D. Leczykiewicz, S. Weatherill (eds.), The Involvement of EU Law in Private Law Relationships, Hart Publishing, Oxford-Portland 2013.

Jurkowska A., 'Antitrust Private Enforcement - Case of Poland' (2008) 1(1) YARS.

Jurkowska-Gomułka A., Publiczne i prywatne egzekwowanie zakazów praktyk ograniczajacych konkurencję: $w$ poszukiwaniu zrównoważonego modelu wspótistnienia, Wydawnictwo Naukowe Wydziału Zarządzania Uniwersytetu Warszawskiego, Warszawa 2013.

Kaliński M., Szkoda na mieniu i jej naprawienie, CH Beck, Warszawa 2011.

Karlsson K., Hansson P., 'Sweden' [in:] J. Buhart, Leniency Regimes: Jurisdictional Comparisons, Sweet \& Maxwell, London 2012.

Kersting Ch., 'Removing the Tension Between Public and Private Enforcement: Disclosure and Privileges for Successful Leniency Applicants' (2014) 5(1) Journal of European Competition Law \& Practice 
Komninos A.P., 'The Relationship between Public and Private Enforcement: quod Dei Deo, quod Caesaris Caesari' [in:] P. Lowe, M. Marquis (eds.), European Competition Law Annual 2011: Integrating Public and Private Enforcement of Competition Law Implications for Courts and Agencies, Hart Publishing, Oxford-Portland 2014.

Landolt P.L., Modernised EC Competition Law in International Arbitration, Kluwer Law International, the Hague 2006.

Niels G., Noble R., 'Quantifying Antitrust Damages - Economics and the Law' [in:] K. Hüschelrath, H. Schweitzer (eds.), Public and Private Enforcement of Competition Law in Europe: Legal and Economic Perspectives, Springer, Berlin-Heidelberg 2014.

Odudu O., 'Developing private enforcement in the EU: Lessons from the Roberts Court' (2008) 53(4) The Antitrust Bulletin.

Piszcz A., 'Dyrektywa odszkodowawcza 2014/104/UE - przegląd niektórych rozwiązań' (2015) 4(4) internetowy Kwartalnik Antymonopolowy i Regulacyjny.

Piszcz A., 'Still-unpopular Sanctions: Developments in Private Antitrust Enforcement in Poland After the 2008 White Paper' (2012) 5(7) YARS.

Podrecki P., 'Civil Law Actions in the Context of Competition Restricting Practices under Polish Law' (2009) 2(2) YARS.

Stadler A., 'Collective Action as an Efficient Means for the Enforcement of European Competition Law' [in:] J. Basedow (ed.), Private Enforcement of EC Competition Law, Kluwer Law International, Aalphen aan den Rijn 2007.

Walle S.V., Private Antitrust Litigation in the European Union and Japan: A Comparative Perspective, Maklu, Antwerpen-Apeldoorn 2013. 